\title{
DEVELOPMENTAL STATE PARADIGM IN ETHIOPIA: LESSONS FOR THE HORN OF AFRICA
}

\section{TEFERI MENGISTU MEKONEN}

Lecturer, Department of Pedagogy and Morality, College of Social Science, Dire Dawa University, Ethiopia

\section{ABSTRACT}

The notion of developmental state was born with the economic success of South East Asian countries in the 1960s and 1970s. However, the actual definition of the term was first coined in 1981 by Chalmers Johnson. The theory describes the importance of state involvement in the economy of a nation with a view to enhance economic development and prosperity. Ethiopia has been exercising developmental state paradigm since 2002 with different challenges and achievements. Exploring the challenges and achievements of the theory from Ethiopian perspectives is important to draw lessons for other Horn of African countries. Indeed, in Ethiopian context the paradigm has increasingly contributed to the economic growth of the state. It has also its own challenges such as dysfunction politics and leadership that contributed for the prevalence corruption and maladministration in the state. In the Horn of Africa, there are notable opportunities that enable other states in the region to practice the developmental state model such as the existence of economic cooperation and regional integration to ensure peace and avoid conflict. However, there are challenges that may hinder to practice it in the region such as the prevalence of poverty, the absence of peace and stability, the absence of democracy and the prevalence of corruption in the region. The objective of this paper is to explore the challenges and opportunities to practice developmental state paradigm in the horn of Africa with a special focus on Ethiopia's emerging experience.

KEYWORDS: Horn of Africa, Developmental State Paradigm \& Ethiopian Developmental State Paradigm

Received: Apr 07, 2017; Accepted: May 06, 2017; Published: May 25, 2017; Paper Id.: IJLSRJUN20176

\section{INTRODUCTION}

\section{Overview of Developmental State Paradigm}

The idea of the "developmental state" has gained credence as theorists sought to explain the impressive rate at which East Asian states were developed during the 1960s and 1970s (Bagachi, 2000). Although, the ingredients of developmental state paradigm were first described by different theorists like Friedrich List, Karl Marx, Alexander Gershenkron and Samuel P. Huntington, F. H. Cardoso and E. Valletta, the actual definition of developmental states was first coined in 1981 by Chalmers Johnson in his work on the East Asian states and especially the Ministry of International Trade and Industry (MITI) in Japan the idea of a strong and capable state as a prerequisite for growth has a long history. Johnson emphasized that a crucial feature of the developmental state was its relations to both the private sector, for whom it set strict social and economic targets and the market where the developmental state was highly involved. Further, he emphasized that the existence of an elite bureaucracy with key influence on the policy making process that was stronger than that of the political or legislative elites and which possessed the power, autonomy and continuity was a strong characteristic of a developmental state (Leftwich, 2000). 
The developmental State is defined as "a State that promotes development" while development can, in turn, be defined as "the improvement in human well-being, education, health care, employment opportunities, among others". The most comprehensive definition of a developmental State is given by the ECA and AUC Economic Report on Africa, which defines it as "one that has the capacity to deploy its authority, credibility and legitimacy in a binding manner to design and implement development policies and programs for promoting transformation and growth, as well as for expanding human capacities" (2011:7). In terms of overall socioeconomic development, such a State aspires to achieve "long-term growth and structural transformation of the economy, with equity" (ECA and AUC, 2011: 7). This makes economic development a top priority of government policy, and designs effective instruments, including appropriate policies, functioning institutions, and formal and informal networks to promote such a goal (UNCTAD, 2009:30).

Thus, a developmental state, in simple terms, is a state that is and seeks to be a strong player in the economy of a nation with a view to enhancing economic development. It means to have a state that puts economic development as the top priority of government policy, and is able to design effective instruments to promote macroeconomic stability and establishes an institutional framework that provides law and order, effective administration of justice and peaceful resolution of conflicts (ECA and AU, 2011).

Apart from the above characteristics of the developmental state paradigm, it is important to describe the basic assumption of Neoliberal ideology that is relevant to this study. Although the intellectual roots of the term can be traced to the postwar writings of Friedrich Hayek and Milton Friedman, neoliberalism first gained widespread prominence during the late 1970s and early 1980s as a strategic political response to the sustained global recession of the preceding decade. In the face of massive inflation, growing unemployment and burgeoning levels of public debt, neoliberalism represented a coherently articulated and thus compelling alternative to political leaders, policy makers and outward-looking segments of the business community desperate for a solution to unfolding economic, social and political crises (Durban, 2010).

The linchpin of this theory is the belief that open, competitive, and unregulated markets, liberated from all forms of state interference, represent the optimal mechanism for economic development (Bourdieu, 1998). Faced with the declining profitability of traditional mass-production industries and the crisis of Keynesian welfare policies, national and local states throughout the older industrialized world began, if hesitantly at first, to dismantle the basic institutional components of the postwar settlement and to mobilize a range of policies intended to extend market discipline, competition, and commodification throughout all sectors of society (Brenner and Theodore, 2002).

However, as Moody (1997:119-120) and others have emphasized, there is a blatant disjuncture between the ideology of neoliberalism and its everyday political operations and societal effects. On the one hand, while neoliberalism aspires to create a "utopia" of free markets liberated from all forms of state interference, it has in practice entailed a dramatic intensification of coercive. On the other hand, whereas neoliberal ideology implies that self-regulating markets will generate an optimal allocation of investments and resources, neoliberal political practice has generated pervasive market failures, new forms of social polarization, and a dramatic intensification of uneven development at all spatial scales. In short, as Gill (1995:407) explains, "the neoliberal shift in government policies has tended to subject the majority of the population to the power of market forces whilst preserving social protection for the strong." During the last two decades, the dysfunctional effects of neoliberal approaches to capitalist restructuring have been manifested in diverse institutional arenas and at a range of spatial scales (Amin 1997; Bourdieu 1998 and Gill 1995). Thus, the disjuncture between the ideology of self-regulating markets and the everyday reality of persistent economic stagnation- intensifying inequality, 
destructive inter place competition, and generalized social insecurity-has been particularly blatant in precisely those political-economic contexts in which neoliberal doctrines have been imposed most extensively (Brenner and Theodore, 2002).

In developing countries, Neoliberalism influence leads streamline the public sector by cutting expenditures, reducing public employees, and withdrawing states active economic role. According to Raymond (1994), since 1990, the government expenditures (as a percentage of GDP) have declined in most developing countries, especially in the social sectors. In fact, one of the main objectives of the so-called structural adjustment program (SAP) adopted by Asian, African, and Latin American countries has been to downsize the public sector in terms of both expenditure and personnel (Haque, 1998).

In the case of Africa, the shift toward a diminishing role of the state and its economic functions is increasingly becoming obvious in Ghana, Nigeria, Tanzania, Zaire, and Zambia (Walton and Seddon, 1994). The character of the emerging neoliberal state in Africa is also reflected in its deeper alliance or partnership with private capital, including both the local business enterprises and transnational firms or investors. This new state-capitalist alliance in Africa is the state's unprecedented affiliation with foreign investors during the period since the early 1980s, which represents a reversal of the postwar state policy to reduce foreign ownership and enhance economic self-reliance. Consequently, it abolishes the welfare citizens related to economic security, health services, and education facilities (King, 1987). In African countries, the contemporary regimes have increasingly moved toward such an anti-welfare option, which is quite evident in their recent attempts to streamline anti-poverty programs, withdraw food and agricultural subsidies, and introduce user fees for public sector services (Haque, 1999b; Tevera, 1995; Walton and Seddon, 1994). Therefore, the 1980s came to be dubbed Africa's lost decade. This was because, SAPs failed to achieve their stated objectives in Africa and Africans were worse off in the 1990s than at the time of their political independence, with high levels of poverty, unemployment, inflation and infrastructural decay prevailing in most countries (Ibid).

By realizing the failure of neoliberalism development paradigm in solving economic problems in developing countries, various writers suggested alternatives to the neoliberal development paradigm. One of the dominant and influential alternatives of neoliberal development paradigm that was forwarded by different scholars was the developmental state paradigm. The concept of the developmental state paradigm offers the possibility of breaking out of the cycle of hunger, poverty, poor infrastructure, and poor human development through state-led economic planning, support to business, where economic and social development can be attained (Sehen Bekele and Tsegaye Regassa, 2012). In this regard, the late Premier Meles Zenawi of Ethiopia noted in one of his occasion: "the key message is that the neoliberal paradigm, which has devastated our economies over the past decades and which has now come back home to roost needs to be discarded before we can do any of the things that we need to do to transform our economies... we need to free ourselves from the constraints of that ideology and pragmatically select our own path of development, based on an empirical evaluation of what works and does not work for us" (ECA and AUC, 2012: 26). Furthermore, in one of his monograph released in Chicago University, he argues that, the neoliberal paradigm is dead end incapable of bringing about the Africa renaissance. To this effect, he adamantly recommended a fundamental shift in a new paradigm and the need for African states in general and Ethiopia in particular to move towards becoming developmental state (Alazar, 2012). 


\section{ETHIOPIAN EXPERIENCE IN DEVELOPMENTAL STATE PARADIGM}

In Ethiopia, the developmental state is viewed as one of the two pillars of the national Renaissance. Coupled with the other pillar; democratic federalism, the establishment and consolidation of an effective developmental state is expected to lead to a national transformation that is no less than a rebirth. The country has set its vision on establishing a democratic rule, a system of good governance and social justice based on the free will of the people. This is meant to contribute to rapid economic growth and to become a country where democratic rule, good governance and social justice reign, upon the involvement and free will of its peoples, and once extricating itself from poverty to reach the level of middle-income economy as of 2020- 2023 (UNDP, 2012).

This paradigm is drawn from South Korea, Taiwan and China, on the premise that the path to accelerated economic growth is through a strong developmental State that creates policy space, encourages and directs investments, and promotes a strong work culture and ethics among the population. Indeed, a close observation of the Ethiopian developmental State model reveals an emulation of the Chinese model, in that there is a de facto one-party State, which prioritizes economic development over the democratization process (Gedion, 2015). Several factors influenced the Ethiopian government to choose the East Asian countries experience for the country's development model.

\section{The Failed Ideology of Neoliberalism}

The establishment of a functioning and capable democratic developmental State in Africa and Ethiopia would encounter several challenges which has been promoted by Western countries and their institutions such as WB and IMF are blamed on because they have had led Africa into another economic dead-end and into a fragile, unstable democracy (ECA and AUC, 2012: 26). Chief among these challenges are the inherently unjust and unfair nature of the global trading system; the institutionalization of the dominance of the North through economic institutions like IMF, World Bank and WTO and the other major challenge is the current global economic crisis and its adverse effects on African countries including Ethiopia given the nature of the economies. Nevertheless, the effect of the financial crisis in Ethiopia has not been visible as such (UNECA, 2013: 56-57). In other side, the neo-liberal paradigm failed to uproot the rent seeking system because it denied the role of government as a dynamic agent of systemic change. The naïve view of "market is good, government is bad," which preached a minimalist government, could not create an agent powerful enough to launch a systemic change in a latecomer developing countries (Teshome, 2012).

According to the late prime Minister of Ethiopia, MelesZenawi, one of the lessons that development draws from South Korea and Taiwan is their ability to free rural communities for rent-seeking private landlords and to build 'developmental structures' through selective government intervention and in Ethiopia, a strong state is guiding the other members of society for development. A government led by a strong leader giving incentives and disincentives to economic actors such as farmers, workers, merchants, entrepreneurs, and foreign investors become instrumental to change behavioral patterns based on value creation rather than rent seeking. Their forms in economic and political governance, which Africa carried out more than three decades ago has generated not growth and transformation, but deindustrialization, the enfeeblement of the African state. For instance, in the 1980s and early 1990s, the Ethiopian economy was on downward trends, with average growth rate of 2.3 percent. In 1996, the national Gross Domestic Product (GDP) was Birr 37 million. After six years that is in 2002 the GDP increased only by Birr 30 million and reached around 67 million (Ibid). 
Furthermore, in spite of the political liberalization of African economies, foreign direct investment (FDI) and development aid flows to the continent have been on the decline. Therefore, the failure of SAPs and political liberalization in the continent, a number of development proposals were put forward as alternatives to SAPs, driven mostly by African scholars and encapsulated in a United Nations Economic Commission for Africa (ECA) policy framework for Africa's economic recovery and rethink of the development path in Africa. This development coincided with the resurgence of the new institutional economics that emphasized the central role of the state in development (Edigheji, 2005)

\section{To Sustain Political Stability and Peace}

The nature of the political system is an additional element or source of autonomy of the democratic developmental state. The internal imperatives coupled with external pressures became the drivers for African states to embrace multiparty democracy. This new wave of political liberalization needs political pluralism and majority rule (Edigheji, 2005). Accordingly, in the last two decades, most African countries have embraced multiparty democracy. However, the democratization process has failed to bring about fundamental and lasting changes in domestic power structures. In addition, the democratization process has not fundamentally led to a qualitative improvement in the living standards of the majority of the African population who continue to be mired in poverty, squalor, hunger and disease and cannot allow all political parties to respond to the demands of the majority or incorporate the masses in any meaningful way (Abrahamsen, 2000; Edigheji, 2005).

The developmental state ought to have the capacity to control domestic infighting and build consensus among the populace on the national development agenda by drawing attention to long-term benefits to all. Ideally, therefore a developmental state needs to be a persuasive state with the competence to mobilize people and resources around its development plan, especially if it is to become a democratic state (UN ECA and AU, 2011).

Ethiopia is considered an anchor country in the region because it has not only significantly improved its stability, registered promising economic development and built strong relations with neighboring countries, but also has become pivotal for regional peace and security. The fact that Ethiopia has transformed from being a source of regional instability and famine to a force for peace and integration is in itself a considerable achievement. After thousands of years as an independent African country, Ethiopia has a long diplomatic history and rich experience in foreign relations (Nuova, 2015).

After the collapse of the old unitary State in Ethiopia, the EPRDF is still struggling for a clear vision around which Ethiopia and its diverse people can rally. Dominating the political space for two decades, the EPRDF has been striving to build a new federal developmental State (Ibid). In this regard the late prime minister of Ethiopia noted that, a democratic developmental state can be defined as one that has the capacity to deploy its authority, credibility and legitimacy in a binding manner to design and implement development policies and programs for promoting transformation and growth, as well as for expanding human capabilities. Such a state takes as its overall socioeconomic goal, the longterm growth and structural transformation of the economy, with equity. Under a democratic developmental state, the fruits of successful development are expected to win popular support, which is confirmed through a series of elections. Thus, the democratic developmental state earns legitimacy and keeps its power for a long time through both economic performance and democratic procedure (Teshome, 2012). 


\section{To End Poverty and Underdevelopment}

Development paradigm is a completely new way of thinking that can bring social, economic and political transformation to improve the wellbeing of the society (FAO, 2011). In Ethiopia, the main national challenge was to end poverty and underdevelopment. Concerned with what could be done with the power to change things for the better, the government went through a rapid phase of implementing the principles of 'democratic development alism' focusing on radical solutions for early humanitarian-crises' warning systems, especially in the drought-prone ecosystem where most of the rural population is localized (Jalal and Sara, 2016).

Accordingly, there are some major opportunities and achievements in the emerging Ethiopian development state. Internally, there is an impressive GDP growth in the past one decade, which has a spillover effect like a reduced level of poverty. Poverty in Ethiopia is reducing at one of the fastest rates in the world. The percentage of the population living below the poverty line also declined from 44 percent in 2000 to 29 percent in 2010 (UNDP, Human Development Index, 2010). The country is also seeking to create a middle income society and a green economy in 2025 . In its vision to become a middle income country by 2025 , Ethiopia has embarked on ambitious national programs to accelerate economic growth with poverty alleviation as a pillar of its development strategy. Since 2003 the government has been working on important plans that brought significant economic growth in the country (Ministry of Finance and Economic Development, 2010; Kate, 2010).

\section{CHALLENGES AND OPPORTUNITIES TO PRACTICE DEVELOPMENTAL STATE PARADIGM IN THE HORN OF AFRICA: ETHIOPIA'S EMERGING EXPERIENCE}

\section{Challenges to Practice, Developmental State Paradigm in the Horn of Africa}

To investigate the challenges and opportunities of developmental state paradigm in the HOA, it needs an analytical basis for drawing comparisons between Ethiopian context and the tangible facts that is viewed in the HOA for thinking about the various ways in which it might interact with one another. The term "Horn of Africa" is not only a geographical expression; it is rather a geopolitical concept. Its extent is therefore fluid and depends on the geopolitics of the region. The proper Horn of Africa consists of Ethiopia, Eritrea, Djibouti, Somalia, the Sudan, and South Sudan. Stretchily, it sometimes also encompasses Kenya and Uganda (“Greater Horn”) (Sintayehu, 2014). For the purpose of this study, the Horn of Africa refers to Ethiopia, Eritrea, Djibouti, Somalia, the Sudan, and South Sudan. Therefore, the analysis of the horn of African problems takes into account the selected countries where the study mainly focuses on by using Ethiopia as emerging experience in the region.

\section{Poverty}

After the end of World War II, with the emergence of newly independent states in Africa and Asia, the international community embraced a state-led model of development, which was intended to bring about industrialization and entrepreneurship through intensive and deliberate effort and state intervention. Except for some East Asian countries, most of the developing countries, especially in Sub Saharan African (SSA) countries were not successful in their development endeavors (Teshome, 2012).

The Horn of Africa is one of the poorest regions of the world. All the countries of the region fall within the bottom 20 per cent of UNDP's Human Development Index. There is little doubt that the alarming number of human casualties, the vast sums some of the governments spend on security, the destruction of property, the disruption of 
economic activity by the large refugee outflows and internal displacements, and the removal of significant portions of the workforce from productive economic activity into the war effort are, no doubt, major factors contributing to the region's general misery(Bereketeab,2013). It is a region where the most basic necessities (clean water, food, health care, and education) are not available too much of the population, and where some countries have adult and infant mortality rates that are among the highest in the continent. The majority of countries are not on track for meeting the Millennium Development Goals (MDG) targets, such as reducing maternal and under-five mortality and addressing food insecurity(WB, 2014).

For instance, in Djibouti, because of the high incidence of poverty (96.5 percent in 2002), the shortage of income generating activities and the precarious living conditions in rural areas, extreme monetary poverty has risen from 34.5 percent in 1996 to 42.2 percent in 2002 and relative poverty increased from 64.9 percent to 74.4 percent during the same period. since Djibouti does not have easily exploitable natural resources or a large rural sector, the prospects for economic growth would have to be found mainly in exploitation of the country's geographical location and particularly through the use of its port as a transit hub (mainly towards Ethiopia) and the development of services, particularly transport(IMF Report, 2009).

In Eritrea, although it is one of Africa's fastest growing economies, is one of the least developed countries in the world, with an average annual per capita income of US\$403 in 2010. Of its population of about 5.3 million, an estimated two-thirds live in rural areas. Eritrea is ranked 177 out of 187 countries in the 2011 United Nations Human Development Index, and the Eritrean diaspora is large and increasing (WB, 2014).

In Somalia with the consequences of conflict, the poverty incidence is 73 percent (61 percent in urban centers and 80 percent in rural areas), with extreme poverty estimated to be 43 percent (ibid) and its macroeconomic framework reflects the country's underlying fragility (World Bank, 2013). And an estimated of 10.6 million people are live in one of the worst-performing economies in Africa, a situation that is exacerbated by frequent droughts and dust storms as a result of climate change. According to the United Nations Development Programme (UNDP), more than 60\% of Somalia's population lives in severe poverty, and almost three quarters of the population lives either in severe poverty or in near poverty. One-third of Somalia's children under the age of five are underweight (Jaffer and Hotez, 2016).

In Sudan, the secession of the South Sudan in 2011 meant the loss of about three-quarters of oil production and a significant correction to past economic trends. The cost of this crisis on the country's human development is already evident: in the years since South Sudan seceded, Sudan itself has slid almost 20 places down the Human Development Index and failing to attract the investment it needs for sustainable growth (UNDP, 2014).

Despite South Sudan's great resource wealth, over half the population lives below the national poverty line. Inequities in access to services, resources, and opportunities, combined with the politics of exclusion and patronage, ineffective governance, and lack of transparency associated with oil revenue, could present a serious threat to physical and economic security and undermine the institutional transformation needed to secure South Sudan's stability and legitimacy(World Bank, 2013).

In this regard, although Ethiopia has achieved good results in terms of economic growth since developmental state' model has realized, however poverty is a major challenge because millions of Ethiopians are still living below poverty level. Therefore, in the Ho A, poverty is predominantly prevailed across the region where around $70 \%$ of the 
population live in rural areas (except in Djibouti, where $70 \%$ of the population lives in urban areas); more than half of those people live on less than US\$1 per day, and smallholder farmers work in conditions of static or declining productivity, vulnerability to drought, and environmental degradation (WB, 2014).

\section{Absence of Peace and Stability in the Region}

Peace, political stability, rule of law and predictability in governance are also considered as a crucial condition for the emergence of the developmental State. For instance, without peace and political stability, investment risks will not be enhanced. This is because peace is a prerequisite for human development-without peace, there can be no stability and without stability there can be no security. Therefore, peace, stability and security are essential conditions for sustainable development and conflict can only contribute to exacerbate the problems that directly related with economic potential, human well-being and the very foundations of the society (Jama and Johansson, 2013).

The Horn of Africa constitutes a Regional Security Complex in which the security problems of each country impacts on the security of all. This indicates that interaction between the states of the region support and sustain the conflicts within the states of the region in a systemic way (Healy, 2008).

For decades, the Horn of Africa has been entangled in conflicts. The most devastating wars in the Horn have been the 30-years Ethio-Eritrean war, the war fought between irredentist Somalia and Ethiopia, and the internal conflicts in the Sudan (Kalib, 2007). There were more than 29 intra-state conflicts and wars in the Horn of Africa between 1961 and 2006. The region of the Horn witnessed many inter-state tensions and wars. The Ethio-Somalia war of 1964 and 1977-1978, the Ethio-Eritrea war of 1998-2000, the Sudan-Eritrea contention of 1994-1998, the Sudan-Ethiopia tension of 1995-1998, and the Kenya-Uganda tension of 2009 are some of the inter-state confrontations in the region (Berouk, 2010) in recent decades has been one of the world's most fragile and unstable regions, experiencing over 200 armed conflicts since 1990 (Paul, 2011).

Consequently, as a result of the complexity and interconnectedness of intra- and interstate conflicts and the concomitant pervasive insecurity are ravaging the region make the Horn of Africa the most conflict-ridden region of the African continent. This has rendered the task of building durable and meaningful peace, security and sustainable development in the region (Bereketeab, 2013).

\section{Absence of Democracy and the Prevalence of Corruption}

As the characteristics of the democratic developmental states shows both development and democracy are ingredients those considered in developmental state paradigm. In the first hand, the introduction of free and fair elections, peaceful successions when governments change, low barriers to political participation and the protection of political and civil liberties. On the other hand, development requires the direction of quite sharp changes affecting the economic and social structure of the society and hence important interests within it (Left wich, 2000). This is because bad governance, characterised for example by corruption and practices of patrimonalismand clientelism, damages state administrative capacity, leads to opaque streams of aid distribution, and deters investment. This in turn limits poverty alleviation, economic growth and development, while also contributing to alienation from the state administration and institutions of government (Helsinki,2006).

Most of the countries of the HOA are known for their centralized states which contribute for the acceleration of instabilities which at the end directs to their fragmentation and failure. The ruling parties ignore power sharing and try to 
preach the people as they are democratic ones. The region is thirsted of peaceful election. Most often the successors came in to power either by force or external support rather than by the full consent of the people. The political crises of the area are explained by civil wars, the restraining of civil liberties and the abuse of human rights (Muhabie, 2015)

For instance, in Ethiopia weak commitment to the democratization process, corruption and weak civil liberties are some of the most notable political problems. There is also apparent challenge with regard to political parties and civil society freedom in the existing Ethiopian developmental State especially after the 2005 elections. As noted in UNECA's Ethiopian governance report, "the EPRDF, however, does not seem to havea genuine belief that opposition parties can play positive roles that could contribute to acceptability and predictability of the political system in a manner that positively impact son regime stability and consensus building" (2012: 51). Accordingly, the overall governance standard in Ethiopia is 1.5 points lower than the average for Africa of 50.1, and the country ranks even lower in the participation and human rights indicators (Nuova, 2015).

In Somalia, although the country introduce federalism currently to satisfy the Somali political leaders, Punt land Government, Somali community elders, Somali Civil Societies as well as the International Organizations, the system is not universally accepted as a political and governmental arrangement among the Somalis. There are sectors from the Somali community who are hesitant, if not against, the federal political system. The religious groups, particularly Al-Shabaab, are basically against any form of secular government. To them it does not matter whether the Somali government is centralized, federal, a confederation or any other decentralized unitary form. They seek what they term "an Islamic government." It appears, at least for the moment, that the form of government they seek is unlikely to materialize, as it is associated with continued violence, discrimination and transnational terrorism(Farah,ND).

Eritrea and Djibouti are the smallest and newest countries in the Horn of Africa. They are also both colonial arte facts. Since its independence, Eritrea has had only one president, IssaiasAfeworki, while Djibouti has had two, the current President, Ismael Omar Ghuelleh, and his predecessor, the late Hassan GouledAptidon. Both countries are poor and sparsely populated. Politically, they are both autocratic (Bereketeab, 2013).

In the Sudan, since he came to power in 1989, the current President, Omar Hassan al-Bashir, Sudan's economy plummeted and social relations further deteriorated. Using these as a pretext, on coming to power he banned unions, political parties and independent newspapers, and placed radio and television under government control. His political association with Sheikh Hassan al-Turabi, the leader of the Muslim Brotherhood in Sudan, had unsettling effects on secularists and Southerners. Their concerns were confirmed when al-Bashir's government imposed shari'a law even in the non-Muslim South, prorogued the Bar Association and enfeebled the judiciary(ibid).

In South Sudan, corruption, nepotism, and ethnicity, are intimately intertwined and feed into each other as major constraints that hamper the effective functioning of the state institutions in the country. Many South Sudanese believe that access to government positions on the basis of tribal affiliation breeds corrupt practices, while it provides sanctuary to the culprits who feel accountable to their respective ethnic communities and leaders hailing from them, not to the state There is the prevalence of corruption, where public funds are expropriated by officials for their personal use; discrimination based ethnicity with respect to government and civil service employment; and nepotism, where people favour their relatives, regardless of merit has been common since independence (Kameir, ND) 
Another challenge is that, with very few exceptions, an African States including Horn African countries does not have the institutional architecture that would constitute the foundation of a democratic developmental State. State institutions in Africa are, for example, bloated, weak, ineffective, and lack the administrative, managerial and technical skills that are required for the effective functioning of a democratic developmental state (UNCTAD, 2009). Therefore, governance quality of the Horn of African states even in comparison with other African states they are behind (Jama and Johansson, 2013). So, as has been suggested, democracy is a major prerequisite for the establishment of a democratic developmental State which thus contribute for sustainable economic development and peace.

\section{Opportunities to Practice, Developmental State Paradigm in the Horn of Africa}

\section{The Growing Regional Economic Integration}

There is a host of embedded factors in the HOA that may contribute to the emergence of regional integration which thus contribute to build developmental state paradigm in the horn of Africa. Such factors could include: sociocultural and economic activities such as cross-border trade and exchanges; common agricultural projects; exchanges of economic services (port services, water resources, mineral and oil resources, etc.); regional investments, and common markets would reinforce regional integration. Economic mechanisms and instruments that are thought to contribute to regional integration may include roads, railways, and creating sea and air links, i.e., communications infrastructures that bring economic integration through linking different regions, and, peoples who formerly lived in isolation leading travel, migration, trade, etc. (Kymlicka\& Patten, 2003).

The notion of economic complementarity in the context of regional integration is also assuming increasing influence. Economic complementarity derives from the presumption that the prevalence of differentiality in resource endowment, it could constitute an inducement for integration through the creation of interdependency among members. The countries of the region are endowed with different natural resources such as livestock, agricultural products, water, energy, oil, and port services. The resources could constitute items of exchange between members who own different resources of specific value to others thereby forming complementary. Cooperation based on material produced by others in exchange with one's products will induce peaceful cooperation instead of belligerent competition (Bereketeab, 2014)

The memorandum of understanding signed in February 2012 between South Sudan, Sudan, Ethiopia, and Djibouti on trade that includes oil pipelines connecting the countries which is an example of cooperation driven by differentiality of endowment. Exchange of oil, port facilities, infrastructure, and energy are another example that could serve to consolidate regional integration. Ethiopia's use of Djibouti's port; Sudan supply to Ethiopia $80 \%$ of its oil needs until 2011, while Ethiopia's reciprocation by supplying Sudan its electricity needs (Woodward, 2013b, pp. 175-176) and Ethiopia and South Sudan have signed an agreement on trade and economic development, electricity, and transportation are some of examples of practical infrastructures that would foster regional integration (Kidist, 2014).

There are also encouraging signs of political momentum for enhanced regional economic interdependence in the HoA. Increasingly, HoA countries are members of Intergovernmental Authority for Development (IGAD), the East African Community(EAC), and the Common Market for East and Southern Africa(COMESA)(WB,2014). For example IGAD which was created in 1996 to supersede the intergovernmental authority on Drought and development (IGADD) has broad mandate to coordinate efforts of its member states (including Djibouti, Ethiopia, Kenya, Somalia, Sudan, south Sudan, Uganda and Eritrea(currently suspended) in achieving peace, prosperity and regional integration(Sarah and Lidet,2014). 
Improving regional infrastructure connectivity can help to improve human development and business competitiveness, and can also help to strengthen trust and cross-border collaboration. Recognizing that cross-border cooperation is critical to more connect and competitive markets to spur faster economic growth, several HoA countries are working to strengthen their economic ties to their neighbors, particularly through support to cross-border infrastructure (WB,2014). For example, Ethiopia and Djibouti currently benefit from mutually beneficial economic cooperation. Ethiopia gets access to the port of Djibouti via a jointly owned railroad, and Djibouti benefits from revenues generated from Ethiopia's use of the port. Another rationale for economic cooperation is that there exists some infrastructure such as roads that connect most of the sates of the Region to build on. A free trade area can also benefit from the existing initiative of IGAD established by the states and supported by international development institutions, donors, and other partners. Indeed, for a successful interregional trade to be viable, it must be complemented by public and private investment. Domestic and foreign private investment is especially crucial to maximize the benefits from a free trade area(Sisay,2006).

In this regard, Ethiopia needs to focus more on the processing of its primarily agricultural raw products to add value and to benefit from the regional trade. Ethiopia processing its exports Livestock products such as such as leather, shoes, purses, leather coats, belts, etc. Currently live cattle are exports to other Horn States and the Middle East. Based on the trade data, Djibouti, Tunisia, Sudan, Algeria and Egypt top the list of countries that serve as destinations of Ethiopia's exports. Ethiopia seems to have more import trade partners outside Africa, and greater imports compared to exports within the region (Jama and Johansson 2013).

Accordingly, since Ethiopia introduced new developmental paradigm in 2002 after evaluating the impacts of structural adjustment between 1991 and 2002, the country has achieved high economic growth and made considerable progress in achieving a number of the Millennium Development Goals. The government has increased its involvement in the economy to create suitable business environment for the market (Teshome: 2012, WB, 2014). According to Government reports, Ethiopia has achieved encouraging development results, maintaining an economic growth rate of 11 $\%$ for the last five years. It has also been reported that the country has come to enjoy the fastest improvement in the Human Development Index (HDI) among Least Developed Countries (LDCs). Moreover, it is determined to accelerate and maintain this development result while strengthening its democratic agenda. It has set for itself a challenging goal of becoming a Democratic Developmental state seeking to create a middle income society and a green economy by 2025(Sehenand Tsegaye, 2012).

\section{Regional Initiatives to Conflict Resolution and Peace Building in the Region}

There are some encouraging initiatives in conflict resolution within and among some of the states of the Region. For instance, Djibouti signed a peace pact in May 2001 with the last armed opposition against the government (World Bank, 2002). The Somalis appear to be making some progress in peace negotiations. The political reconciliation talks among the Somali factions, originally scheduled in April 2002, have just been concluded on a positive note. The Somalis have adopted "a declaration on Cessation of Hostilities and the Structures and Principles of the Somali National Reconciliation Process" at their recent meeting in Kenya on October 27,2002, under the sponsorship of IGAD. The Sudan has signed a successful Peace Agreement with the SPLA in 2005, ending a long war that has claimed 2 million people (Sisay,2006).

The emerging IGAD peace and security architecture promises a lot more mechanisms for the prevention, management and resolution of conflicts in non-violent ways. Despite the challenges, IGAD, in its efforts to contribute to 
regional peace and security, managed to broker peace processes for Somalia, leading to the formation of the Transitional Federal Government, in October 2004 and for Southern Sudan, leading to the signing of the Comprehensive Peace Agreement (CPA), in January 2005. All peace processes are undertaken by IGAD (HAB, 2010)

Similarly, Ethiopia as regional actor and member of IGAD and AU deployed its troops for peacekeeping missions in Abyei-a contentious border region between Sudan and South Sudan under the banner of United Nations Interim Security Force in Abyei (UNISFA) since June 2011 (Kidist, 2014). Ethiopian forces have been also operating in neighbouring Somalia for several years, helping the UN-backed government fight the al-Qaeda-aligned al-Shabab group. Ethiopian troops have given a boost to the security force as it continues to battle against al-Shabab militants. They have served a critical role securing areas in the west of the country, acting independent of the AU mission (Beza, 2014). This deeds plays an indispensable role for the stability of Ethiopia and of the region, which is important factor for the progress of trade, regional integration and for the achievement of development and the Sustainable Development Goals (SDGs) (Milas and Abdel-Latif, 2000).

Accordingly, the government has established strong political ties with all countries of the HoA with the exception of Eritrea. In addition to the establishment of strong relations with the countries, the government has been engaged in different activities that will ensure the peace and security of the sub-region, thereby help the sub-region attain development and prosperity as part of its commitment to the region (GCAO, 2012). Consequently, the country has the largest standing army in Sub-Saharan Africa and the third in Africa. Beyond its size, its military experience in both conventional and antiguerrilla warfare (Makonnen and Lulie, 2014) makes it one of the few countries in the continent with recent conventional anti-guerrilla and modern peacekeeping experience. It is the best equipped military in the region, with ground and air force personnel numbering 200,000 to 250,000 (Berrouk 2011, 89) and has managed through recent, to ensure its position as an active regional actor while resisting the global and neighboring threats leading to the politicization of religion (Abdel-Latif, 2013).

\section{CONCLUDING REMARKS}

In conclusion, it is important to note the presence of several challenges and opportunities to promote a Developmental state paradigm in the Ho A. With regard to its challenges, all the horn countries are characterized by the absence of peace and stability, absence of democracy, the prevalence of corruption and poverty which has not yet been solved In other hand, the opportunities to promote developmental state paradigm in the Ho A are the growth of subregional economic integration that would benefit the member states in terms of energy generation, transportation, trade and also in the areas of education and health. In this regard, Ho A member states are currently increasingly involved in regional economic organizations such as COMESA, ECA and IGAD.

In addition, all of the horn countries have made some progress in cooperation on conflict prevention and promoting peace around the region. This current effort in conflict resolution and peace building in the Region will enable them to promote a developmental state paradigm which may contribute to sustainable development in the region. Successful peace building could provide the key to unlock other seemingly intractable regional situations, not only bringing war to an end, preventing future conflict, and stabilizing post-war scenarios, but also fostering good governance as well as development, poverty reduction, and economic recovery.

The countries of the region can learn from the developmental State paradigm experiences of Ethiopia in many 
ways. First, Ethiopia's peace and stability are key points by virtue of its long history, demographic power of 100 million, and cultural and religious diversity in the Horn. In this regard, Ho A member countries may learn lessons since they have shared experiences like ethnic and cultural similarity that is an important aspect of creating diplomacy at the regional level and thus foster regional peace and stability. Secondly, several processes and structures that have been put into place to help millions of Ethiopia's poor to break free from the intergenerational cycle of poverty and continued economic growth by using its natural wealth including a huge potential in agriculture and livestock in the Horn. Since almost all countries are rich in natural resources, including both renewable and nonrenewable sources of energy; they have vast groundwater reserves; great untapped agricultural capacity; and a business community that has a strong influence on economic growth, level of employment, demand for other goods, food security, and overall poverty reduction in all countries of the region.

Despite this economic performance, Ethiopia is facing the challenges of low level of democracy and prevalence of corruption, due to dysfunction politics and leadership. The solution now and in the future will be promoting democracy and development correspondingly. Thus, if other horn African states to practice developmental state paradigm, it is essential to use both ingredients without prioritizing one over the other. In so doing, they may practice democratic developmental State paradigm in the region that would contribute for the peace and security, development, and democratic governance of the horn in general.

\section{REFERENCES}

1. Abrahamsen, R. (2000). Disciplining Democracy: Development and Good Governance in Africa. London: Zed Books,

2. Alazar, K. (2012). The Late Prime Minister MelesZenawi and the Issue of State, Democracy and Development, Addis Ababa, Ethiopia

3. Amin, S. (1997). Capitalism in the Age of Globalization. London: Zed

4. Bagchi, A. (2000). "The Past and Future of the Developmental State”, The Journal of World-system Research, Vol.5, PP. 398442.

5. Bereketeab R. (2013). The Horn of Africa intra-State and inter-State conflicts and Security. Pluto Press345 Archway road, London and Nordic Africa Institute, Uppsala, Sweden

6. Bereketeab, R. (2014). The Challenges of Regional Integration in the Horn of Africa, Journal of US-China Public Administration. The Nordic African Institute, Uppsala, Sweden

7. Berouk M.(2010). The Horn of Africa as a Security Complex: Towards a Theoretical Framework. Viewed 17 June 2012, http:// www.psa.ac.uk/journals/pdf/5/2010/1256_1136.pdf

8. Beza, G.(2014). Ethiopia's ever-growing leadership role in the African Union: TigraiOnlne - February 04,

9. Bourdieu, P.(1998), Acts of Resistance: Against the Tyranny of the Market. New York: Free Press

10. Brenner, N. and Theodore, N. (2002). The Urbanization of Neoliberalism: Theoretical Debates, Cities and the Geographies of “Actually Existing Neoliberalism”. Cambridge: Polity Press.

11. ECA and AUC. (2011). Economic Report on Africa 2011: Governing Developments in Africa- the Role of the State in Economic Transformation. Addis Ababa, Ethiopia: Economic Commission for Africa Publishing.

12. ECA and AUC. (2012). African Governance Newsletter: A quarterly Newsletter on Current Development on Governance in Africa. Vol. 3, Nos. 1 \& 2, January-June 2012. Addis Ababa, Ethiopia: Economic Commission for Africa Publishing. 
13. Edigheji, O. (2005). A Democratic Developmental State in Africa? A Concept Paper. CPS "State Series." Johannesburg, South Africa: Center for Policy Studies.

14. Edigheji, O. (2010). Constructing a Democratic Developmental State in South Africa, Cape Town: HSRC Press.

15. FAO. (2011). The State of Food and Agriculture: Women in agriculture: closing the gender gap for development

16. Farah IssaM. (ND). Somalia Federalism: Achievements, Challenges and Opportunities

17. Gedion G. (2015). An African Developmental State: Ethiopia's Emergent Experience, Regional Conference on Building Democratic Developmental States for Economic transformation in Southern Africa 20 - 22 july 2015:Pretoria, south Africa

18. Gill, S. (1995). Globalisation, market civilisation and disciplinary neoliberalism. Millennium 24:399-423

19. Government Communication Affairs Office (GCAO). (2012). Report on Ethiopia's Foreign Policy and its Achievements, Addis Ababa, Ethiopia, April 2012

20. Haque, M. (1998). "New Directions in Bureaucratic Change in Southeast Asia: Selected Experiences", Journal of Political and Military Sociology 26 (1): 96-114.

21. Haque, M. (1999b) "The Fate of Sustainable Development Under the Neoliberal Regimes in Developing Countries", International Political Science Review 20 (2): 199-222.

22. Healy, S. (2008). Lost Opportunities in the Horn of Africa: How Conflicts Connect and Peace Agreements Unravel. A Horn of Africa Group Report, Royal Institute of International Affairs

23. Helsinki, H. (2006). Conflict Prevention, Management and Reduction in Africa. Institute of International Affairs \&the Centre for International Cooperation and Security, ISBN-13: 978-951-724-577-7 ISBN-1 : 951-724-577-70,

24. Horn of Africa Bulletin. (HAB). (2010). A nascent peace and security architecture in the Horn of Africa: prospects and challenges, Volume 22, No. 3:The Life \& Peace Institute,

25. IMF.( 2009). Djibouti: Poverty Reduction Strategy Paper, International Monetary Fund Washington, D.C. Country Report No. 09/203, July 2009

26. Jaffer A, Hotez PJ. (2016). Somalia: A Nation at the Crossroads of Extreme Poverty, Conflict, and Neglected Tropical Diseases. PLoSNegl Trop Dis 10(9): e0004670. doi:10.1371/journal. pntd.0004670

27. Jalal, A. and Sara. (M.2016). Ethiopia: Emergence and Positive Change in a Turbulent Geopolitical Context, OCP Policy Center ISSN N²421-9479 Dépôtlégal N²015PE0055

28. Jama, A. and Johansson, U. (2013). Peace and Security: Keys to Stability and Sustainable Development in the Horn of Africa, A Report of the $11^{\text {th }}$ Horn of Africa Conference, Lund, Sweden, June 8-10, 2012

29. Kalib, Y. (2007). Horn of Africa: Conflicts and Consequences. A paper presented at the 4 International Conferences on Ethiopian Development Studies on Peace and Development in Ethiopia and Northeast Africa held on August 2-4, 2007, Western Michigan University.

30. Kameir E.(ND). The Political Economy of South Sudan. The African Development Bank, A Scoping Analytical Study

31. Kate, A. (2010). “Ethiopia: Dilemmas of higher education massification”, 05 September 2010, Issue No. 61.

32. Kidist, M. (2014). The Role of Regional Powers in the Field of Peace and Security: The Case of Ethiopia: Horn of Africa Security Dialogue

33. King, D.S. (1987). The New Right: Politics, Markets and Citizenship. Chicago, Ill.: Dorsey Press. 
34. Kymlicka, W., \& Patten, A. (2003). Language rights and political theory. Annual Review of Applied Linguistics, 23, 3-21.

35. Left wich, A. (2000). States of Development: On the Primacy of Politics in Development.

36. Lionel, C. Roy, L. and Kjetil, T. (2009). Conflict and Peace in the Horn of Africa, Review of African Political Economy No. 120:151-163 ROAPE Publications Ltd., 2009

37. Ministry of Finance and Economic Development (MOFED).(2010). Federal Democratic Republic of Ethiopia, Growth and Transformation Plan 20 10/11-20 14/15 November 2010 Addis Ababa, Ethiopia

38. Muhabie, M.(2015). The Root Causes of Conflicts in the Horn of Africa. American Journal of Applied Psychology. Vol. 4, No. 2, 2015, pp. 28-34. doi: 10.11648/j.ajap.20150402.12

39. Nuova, E. (2015). Promoting Stability and Development in Africa: How to Foster Cooperation between Public and Private Sectors, IstitutoAffariInternazionali (IAI)

40. Paul, W. (2011). Horn of Africa: Webs of Conflict and Pathways to Peace. The Wilson Center, Washington, D.C. Regional Initiative in Support of the Horn of Africa, World Bank, 2014

41. Sarah, C. Lidet T.(2014). Civil Society and Regional Peace building in the Horn of Africa: A review of present engagement and future opportunities. Life \& Peace Institute, Addis Ababa, Ethiopia

42. Sehen, B. and Tsegaye, R. (2012). Democratization in a Developmental State: The Case of Ethiopia Issues, Challenges, and Prospects; Governance and Human Rights Unit, UNDP Ethiopia.

43. Sintayehu K. (2014). The Horn of Africa: Some Explanations for Poverty and Conflicts, ERJSSH 1 (1), September-October 2014

44. Sisay A. (2006) Prospects for Peace, Development and Cooperation in the Horn of Africa. International Conference on the State of Affairs of Africa (ICSAA),

45. Teshome A. (2012). Meles's Development Paradigm and Its Impacts on Economic Transformation in Ethiopia. Addis Ababa, Ethiopia,

46. Tevera, D. (1995) “The Medicine that Might Kill the Patient: Structural Adjustment and Urban Poverty in Zimbabwe”, in D. Simon et al., eds., Structurally Adjusted Africa: Poverty, Debt and Basic Needs. London: Pluto Press.

47. Tewodros, M. \& Lulie, H. (2014). Ethiopia: Regional Integration and the COMESA Free Trade Area, The South African Institute of International Affairs (SAIIA), African perspectives. Global insights

48. Thurbon, E. (2010). 'Ideas and Industrial Governance in Australia: Has the Influence of Neoliberalism been Overstated ?' University of New South Wales, Australia

49. UN ECA and AU.(2011). Economic Report on Africa: Governing Development in Africa-the Role of the State in Economic Transformation. Addis Ababa: UN ECA, 2011, p. 7.

50. UNCTAD. (2009). The Least Developed Countries Report 2009: The State and Development Governance. Geneva: UNCTAD.

51. UNDP. (2014). Update on Macroeconomic Developments in Sudan: All demographic, under-five and maternal mortality rates from UNICEF country profiles, September 2014

52. UNDP.(2012). MDGs in Ethiopia-Analysing Regional Performance and Disparities in Health Outcomes: A Report. UNDP Ethiopia.

53. Walton, J. and D. Seddon. (1994). Free Markets \& Food Riots: The Politics of Global Adjustment. Cambridge: Blackwell Publishers. 
54. WB.(2014). World Bank Regional Initiation Department Africa Region : Regional Initiative in Support of Horn of Africa, October 23

55. Woodward, P. (2013b). Crisis in the Horn of Africa: Politics, piracy and the threat terror. London and New York: I.B. Tauris.

56. World Bank, (2002). African Regional Integration Arrangements,www.jomodesign.com/worldbank/

57. World Bank. (2013). Interim Strategy Note (FY2012-FY2014) for the Republic of South Sudan, January 2013.

58. World Bank.(2013). Interim Strategy Note (FY14 - FY16), for the Federal Republic of Somalia, November 11, 2013. 